\title{
Bacillus species (BT42) isolated from Coffea arabica L. rhizosphere antagonizes Colletotrichum gloeosporioides and Fusarium oxysporum and also exhibits multiple plant growth promoting activity
}

Tekalign Kejela ${ }^{1,2^{*}}$, Vasudev R. Thakkar ${ }^{3}$ and Parth Thakor ${ }^{3}$

\begin{abstract}
Background: Colletotrichum and Fusarium species are among pathogenic fungi widely affecting Coffea arabica L., resulting in major yield loss. In the present study, we aimed to isolate bacteria from root rhizosphere of the same plant that is capable of antagonizing Colletotrichum gloeosporioides and Fusarium oxysporum as well as promotes plant growth.

Results: A total of 42 Bacillus species were isolated, one of the isolates named BT42 showed maximum radial mycelial growth inhibition against Colletotrichum gloeosporioides (78\%) and Fusarium oxysporum (86\%). BT42 increased germination of Coffee arabica L. seeds by 38.89\%, decreased disease incidence due to infection of Colletotrichum gloeosporioides to $2.77 \%$ and due to infection of Fusarium oxysporum to $0(p<0.001)$. The isolate BT42 showed multiple growth-promoting traits. The isolate showed maximum similarity with Bacillus amyloliquefaciens.

Conclusion: Bacillus species (BT42), isolated in the present work was found to be capable of antagonizing the pathogenic effects of Colletotrichum gloeosporioides and Fusarium oxysporum. The mechanism of action of inhibition of the pathogenic fungi found to be synergistic effects of secondary metabolites, lytic enzymes, and siderophores. The major inhibitory secondary metabolite identified as harmine ( $\beta$-carboline alkaloids).
\end{abstract}

Keywords: Biocontrol, Colletotrichum gloeosporioides, Fusarium oxysporum, Plant growth promoting rhizobacteria, Coffea arabica L

\section{Background}

The word coffee comes from the name of the place in Ethiopia called "Kaffa". "Kaffa" means the plants of God [1]. Coffee classified under the family of Rubiaceae in the genus Coffea. There are many species of coffee, but the two most widely cultivated are C. arabica $\mathrm{L}$. and $C$. canephora (robusta). Southwestern and southeastern Ethiopia considered as the origin of $C$. arabica $\mathrm{L}$.

\footnotetext{
* Correspondence: ftekakej@gmail.com

'Department of Biology, Faculty of Natural and Computational Sciences, Mettu University, Mettu, Ethiopia

${ }^{2}$ Present Address: BRD school of Biosciences, Sardar Patel University, Vallabh

Vidyanagar 388120 , India

Full list of author information is available at the end of the article
}

(Arabica coffee) [2]. Of the total world production of coffee, C. arabica L. takes the lion's share, which is $66 \%$ and C. canephora only of $34 \%$. Although coffee produced in few countries, it is the most traded agricultural products around the globe after oil. According to a 2014 report by the International Coffee Organization, the top six coffee producing countries in our globe are Brazil, Vietnam, Colombia, Indonesia, Ethiopia, and India. In Ethiopia, it is mostly exported cash crop that accounts for $69 \%$ of all agriculturally export commodities and it was estimated that at least 15 million of Ethiopian population depend directly or indirectly on coffee production 
[1]. Similarly, there are around 250,000 coffee growers in India; $98 \%$ of them are small-scale growers.

One of the challenges in coffee production industry is the impact of the coffee pathogen, especially pathogenic fungi, which results in reduced production and low quality of coffee seeds [3]. The yield loss due to the fungal pathogens, especially Colletotrichum species, and Fusarium species have been repeatedly reported from coffee growing areas [4-7]. Coffee berry disease caused by Colletotrichum khawae is causing a major yield loss in coffee growing areas of Ethiopia [8, 9]. C. khawae and C. gloeosporioides are the most abundantly found pathogens in diseased coffee seeds [9]. C. gloeosporioides also listed as one of important coffee pathogens by the coffee board of India. Apart from the coffee plant, C. gloeosporioides Penz possesses a broad host range (470 genera of plants) and ranked as the most devastating plant pathogen in the genus Colletotrichum [10, 11]. Fusarium species also cause serious impact on the coffee production industry. Coffee wilt disease caused by Gibberella xylarioides (anamorph: Fusarium xylarioides) causes approximately $3360 t$ of coffee yield losses each year in Ethiopia [12]. This production loss causes a great economic loss around the world, for example, Ethiopia loses an estimated 3.7 million American dollars every year.

Chemical pesticides used currently to control coffee pathogens needed to spray 7-8 times annually which is laborious and expensive. Furthermore, the extensive use of chemical pesticides also contributes to emerging pesticide resistant pathogens. The uses of chemical pesticides and fertilizers have also a negative impact on the indigenous microbial community by disturbing the natural distribution of microbial niche. The coffee cultivated with no or less application of chemical pesticides have more consumer acceptance. In addition, the use of environmentally friendly and sustainable way of disease controlling system gained major attention in recent years. In this view, rhizosphere is the ideal place to search potential rhizobacteria that are capable of promoting plant growth and suppressing the phytopathogens.

Extensive studies of the use of plant growth promoting rhizobacteria (PGPR) for disease control and plant growth promotion in the coffee plant have not been reported. It is necessary and useful to evaluate and document indigenous beneficial microbe isolated from coffee and test them against coffee pathogens. In the current study, several bacteria from the rhizosphere of C. arabica $\mathrm{L}$. were isolated and the potent bacterium antagonistic to C. gloeosporioides and F. oxysporum was chosen, which also showed multiple plant growth promoting activity. The potent isolate showed maximum similarity with Bacillus amyloliquefaciens by $16 \mathrm{~s}$ rRNA gene sequencing and by blasting this sequence against reference sequences found in the international nucleotide database using the program called BLASTn.

\section{Results}

\section{Isolation of Bacillus species}

From the rhizosphere of Coffea arabica L. 42 pure Bacillus species were isolated. These isolates were grampositive, catalase-positive, spore-forming, rod-shaped and able to survive at $80{ }^{\circ} \mathrm{C}$ (Fig. 1). It forms central/sub terminal/ellipsoidal endospores. The bacterium grew at the temperature range of $15-50{ }^{\circ} \mathrm{C}$, the optimum temperature of $30-42^{\circ} \mathrm{C}$, optimum $\mathrm{pH}$ of 7 in aerobic condition.

\section{The antagonistic effect of Bacillus species isolates against} C. gloeosporioides and F. oxysporum

Bacteria isolates were studied against two fungal pathogens $C$. gloeosporioides and F. oxysporum for radial mycelial growth inhibition. Sixteen Bacillus species isolates showed greater than $40 \%$ mycelial growth inhibition. Among these isolates, BT42 showed maximum radial mycelial growth inhibition against $C$. gloeosporioides (78\%) and F. oxysporum (86\%) (Fig. 2). Therefore, BT42 selected for in vitro and vivo studies.

\section{Identification of isolate}

The isolate BT42 selected for identification because it showed highest mycelial growth inhibition of C. gloeosporioides and $F$. oxysporum when compared to other isolates. The 16S rRNA gene amplified from the genomic DNA of BT42 (1.5 kb) sequenced and analyzed by nucleotide Blast analysis (BLASTn). The BT42 (NCBI

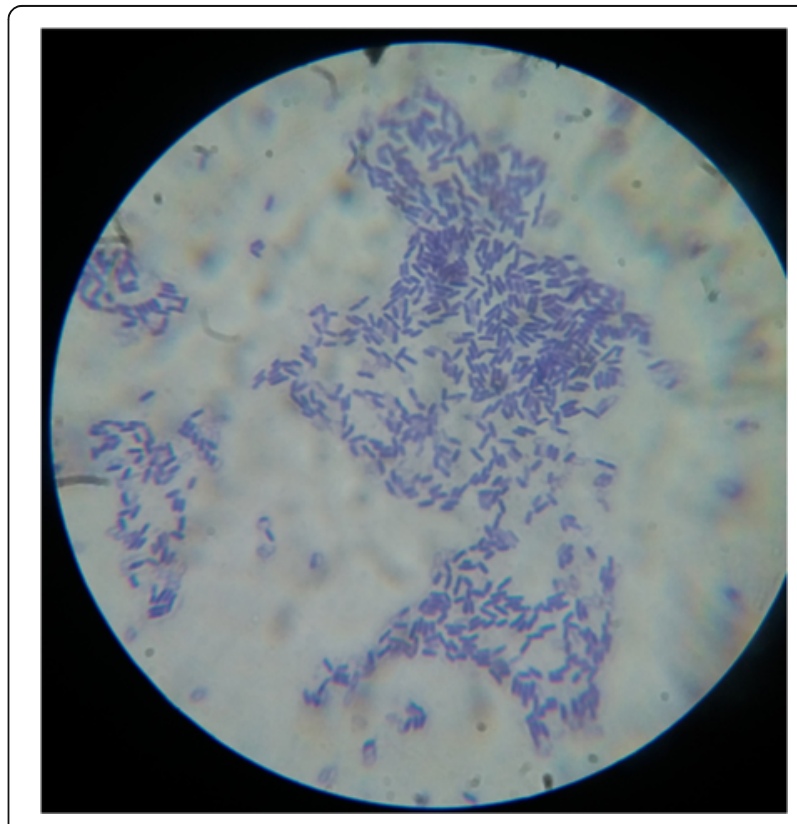

Fig. 1 Gram staining of cells of Bacillus sp BT42 isolated from Coffea arabica L. rhizosphere 


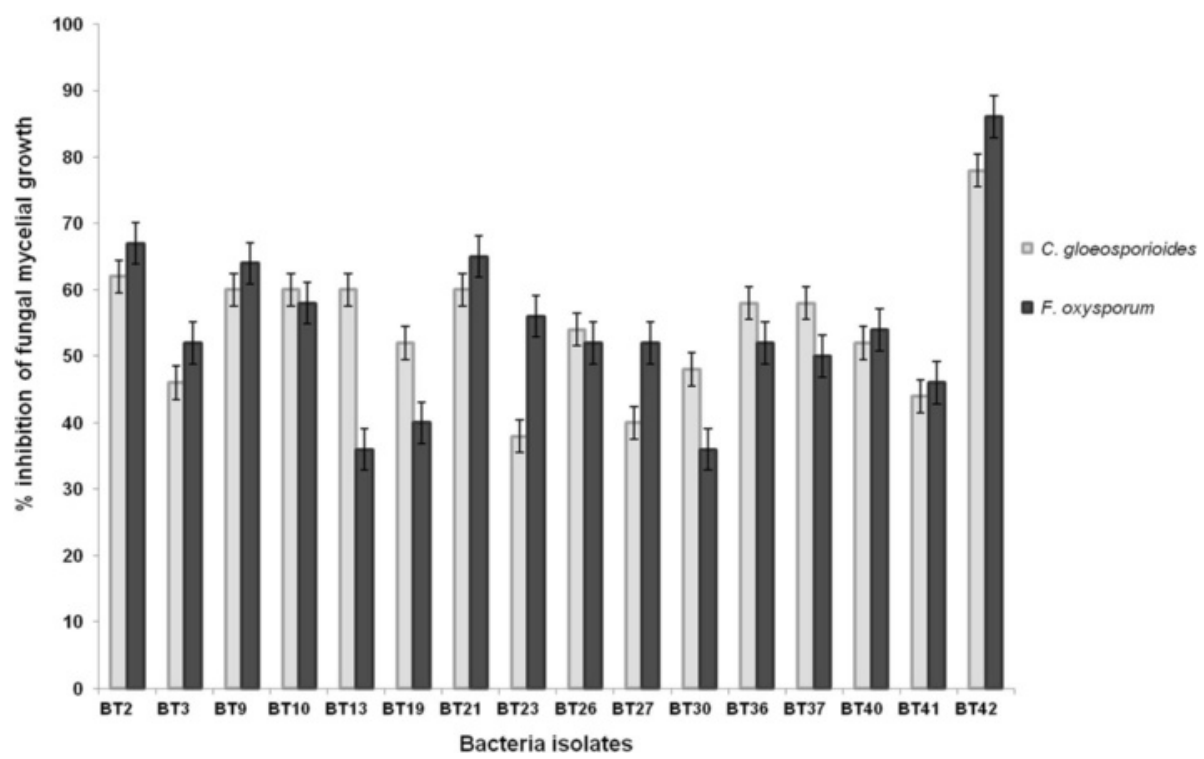

Fig. 2 In vitro mycelial growth inhibition of C. gloeosporioides and F. oxysporum by Bacillus species isolated from Coffea arabica L. rhizosphere. Error bars represent \pm Standard Deviation (SD). Values are means of three replicates

accession number KT220617) showed maximum similarity with Bacillus amyloliquefaciens (Fig. 3). When compared to Ez taxon database it showed $86.55 \%$ similarity with Bacillus amyloliquefaciens subsp. plantarum FZB42.

\section{Plant growth promoting characteristics of Bacillus species BT42}

BT42 produced $14.56 \pm 0.862 \mu \mathrm{g} / \mathrm{ml}$ IAA in the medium supplemented with L-tryptophan, produced ammonia, solubilized $6.36 \pm 0.48 \mu \mathrm{g} / \mathrm{ml}$ tri-calcium phosphate, formed $37.5 \pm 0.56 \mathrm{~mm}$ of holo zone by solubilizing insoluble zinc oxides (Fig. 4), produced $75.90 \pm 1.24 \%$ siderophore units in the iron free succinate medium, grew on the media supplemented with 1-aminocyclopropane-1-carboxylic acid (ACC) as a sole nitrogen source, and formed robust pellicles when grown in LB broth at the liquid air interference.

\section{Bioassay}

Effect of BT42 on seed germination and disease incidence

To study the effect of BT42 on germination of $C$. arabica L. seeds, suspension of overnight grown rhizobacteria (0.5 McFarland Standard) was coated on the seeds of $C$. arabica $L$ and the effect on germination were observed and recorded. Percentage germination of $C$. arabica $L$.

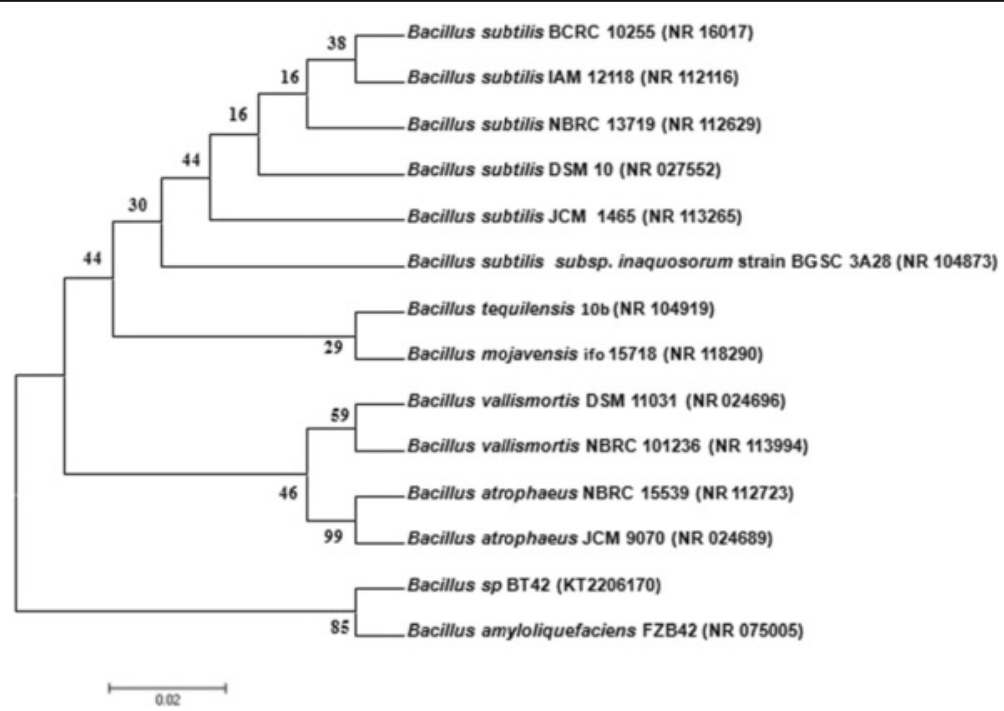

Fig. 3 Neighbor joining tree of isolated Bacillus sp. BT42 and closely related species. Bootstrap values based on 1,000 replications 


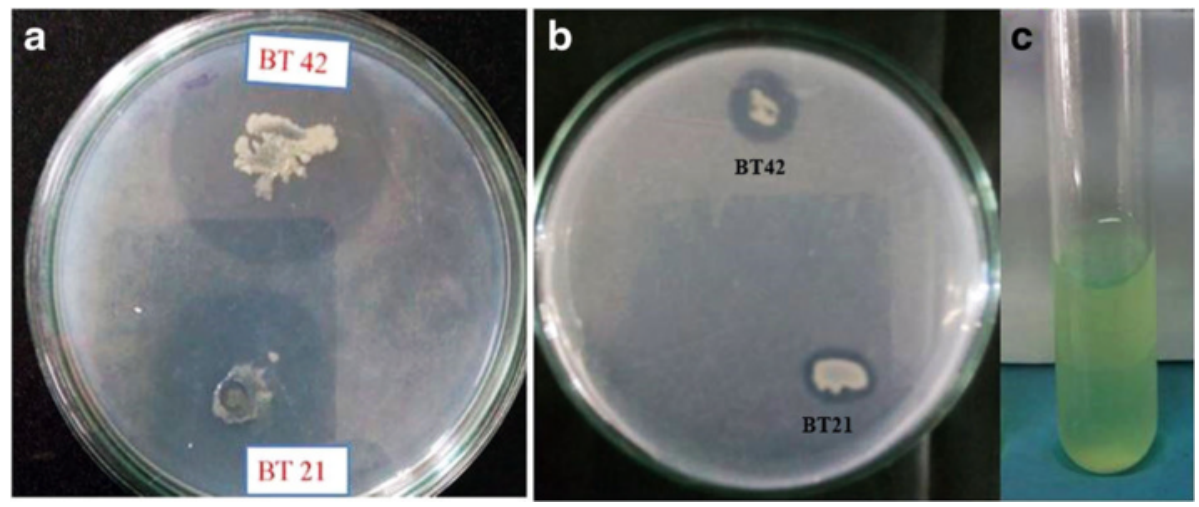

Fig. 4 Zinc solubilization (a), Tricalcium phosphate solubilization (b) and Siderophore production (c) by Bacillus species(BT42)

improved from $50 \%$ of untreated seeds to higher in the presence of rhizobacteria (Table 1). None of the C. arabica $L$. seeds infected with $C$. gloeosporioides could germinate (Fig. 5a), but in the presence of BT42, there was an improvement in germination percentage and decrease in the disease incidence. The disease incidence was as high as $91.67 \%$ when the seeds infected by C. gloeosporioides spore suspension alone. Disease incidence reduced by $88.9 \%$ when the BT42 was simultaneously surface coated with C. gloeosporioides (Table 1).

\section{Mechanisms of inhibition}

\section{Lytic enzyme production}

BT42 formed a clear zone around its colony on the medium supplemented with colloidal chitin, laminarin, tween 80 and skim milk, indicating extracellular production of chitinase, $\beta-1,3$ glucanase, protease, and lipase respectively. The correlation of diameter of hole zone of chitinase with mycelial growth inhibition of $C$. gloeosporioides $(r=$ 0.905, $P<0.05)$ and $F$. oxysporum $(r=0.780, P<0.05)$ were positive. Similarly, the correlation of diameter of hole zone

Table 1 Effects of selected rhizobacteria isolates on germination of $C$. arabica $L$. seeds and on disease incidence caused by C. gloeosporioides and F. oxysporum

\begin{tabular}{lll}
\hline Bioassay & Parameters & \\
\cline { 2 - 3 } & Germination \% & DI (\%) \\
\hline Control (untreated seeds) & $50 \pm 5.33^{\mathrm{a}}$ & $0^{\mathrm{a}}$ \\
C. gloeosporioides infected & $0^{\mathrm{b}}$ & $91.67 \pm 8.33^{\mathrm{b}}$ \\
BT42 treated & $88.89 \pm 4.81^{\mathrm{c}}$ & $0^{\mathrm{a}}$ \\
BT42 + C. gloeosporioides & $72.22 \pm 2.83^{\mathrm{d}}$ & $2.77 \pm 4.81^{\mathrm{a}}$ \\
Control (untreated seeds) & $50 \pm 5.33^{\mathrm{a}}$ & $0^{\mathrm{a}}$ \\
F. oxysporum infected seeds & $11.11 \pm 4.81^{\mathrm{b}}$ & $88.89 \pm 9.62^{\mathrm{b}}$ \\
BT42 treated & $88.89 \pm 4.81^{c}$ & $0^{\mathrm{a}}$ \\
BT42 + F. oxysporum & $80.56 \pm 12.72^{c}$ & $0^{\mathrm{a}}$ \\
\hline
\end{tabular}

Values followed by dissimilar letters in each column indicate significance difference (one-way ANOVAs, Duncan's test). Values are means of three replicates of $\beta-1,3$ glucanase with mycelial growth inhibition of $C$. gloeosporioides $(r=0.604, P<0.01)$ and $F$. oxysporum $(r=$ $0.802, P<0.01$ ) were also positive (Fig. 6 ).

\section{Production of Antifungal compounds}

To investigate the production of antifungal metabolite/s, $5 \mathrm{ml}$ of growing culture of BT42 (in three replicates) was taken at different time intervals and its supernatant was tested for antifungal activity against $C$. gloeosporioides and F. oxysporum by agar well diffusion method. The highest antifungal activity was found in $48 \mathrm{~h}$ old culture grown at $30{ }^{\circ} \mathrm{C}$ under shaking condition of $150 \mathrm{rpm}$ (Fig. 7).

\section{Stability of antifungal compounds}

The ethyl acetate extract of 48-hour-old cell-free culture was checked for its antifungal activity at different temperatures and it was found stable for more than 3 months at $4{ }^{\circ} \mathrm{C}$, for $1 \mathrm{~h}$ at $100{ }^{\circ} \mathrm{C}$ and for 3 months at room temperature.

\section{Separation and purification of antifungal compound}

The ethyl acetate extract was separated on the silica thin layer chromatography (TLC) plate using isopropanol: ammonia: water $(10: 1.5: 1)$ as the solvent system (Fig. 8a). Five bands with $\mathrm{R} f$ values $0.33,0.50,0.61,0.72$ and 0.87 were detected. Compounds corresponding to a metabolite in each band named from bottom to top as $\mathrm{C} 1, \mathrm{C} 2, \mathrm{C} 3, \mathrm{C} 4$, and C5 were assayed for antifungal activity against $C$. gloeosporioides and $F$. oxysporum. Among the five bands, the metabolite named as $\mathrm{C} 1$ showed significant mycelial growth inhibition of $C$. gloeosporioides (Fig. 8b) and F. oxysporum (Fig. 8c) and was selected further for characterization and identification. The purity of the band showing maximum antifungal activity (that is $\mathrm{C} 1, R f$ 0.33) was checked again using different solvent systems on TLC, which showed a single band. 


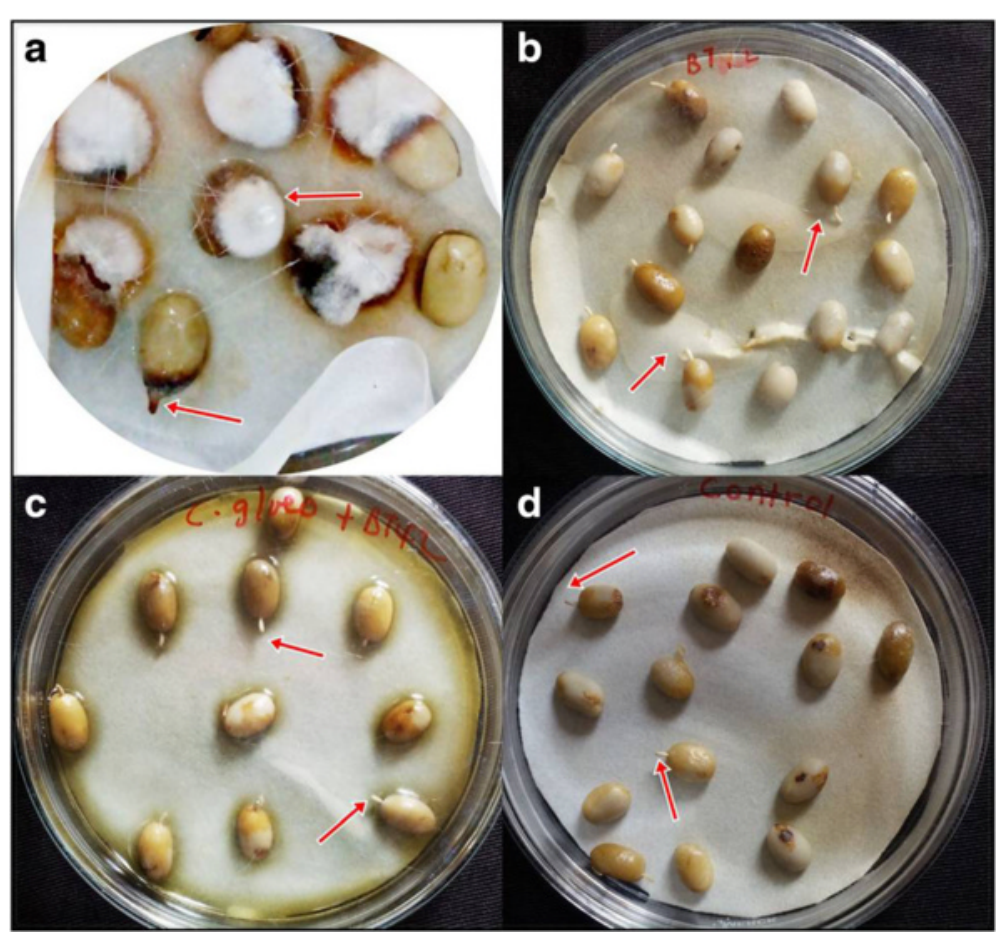

Fig. 5 Effect of inoculation of BT42 on coffee seed germination. C. gloeosporioides infected (a), BT42 treated (b), BT42+ C. gloeosporioides (c) and untreated (d)

\section{Characterization and identification of potent compound}

Purified compound $\mathrm{C} 1$ was subjected to spectral scan analysis from $100-1100 \mathrm{~nm}$ to identify its absorbance maxima, which was found to be $205 \mathrm{~nm}$. The compound $\mathrm{C} 1$ was found to be soluble in methanol and sparingly soluble in water. Liquid chromatographymass spectrometry (LC-MS) data of $\mathrm{C} 1$ showed the retention time $4.9 \mathrm{~min}$ by the photodiode anode (PDA) detector. The same fragment was subjected to mass spectrometry (MS) analysis. MS analysis clearly indicated that purified $\mathrm{C} 1$ compound has the molecular weight 212.10 (Fig. 9a). For the investigation of the numbers of carbon, hydrogen, oxygen and nitrogen atoms, absolute intensity of $\mathrm{M}+1$ peak and natural

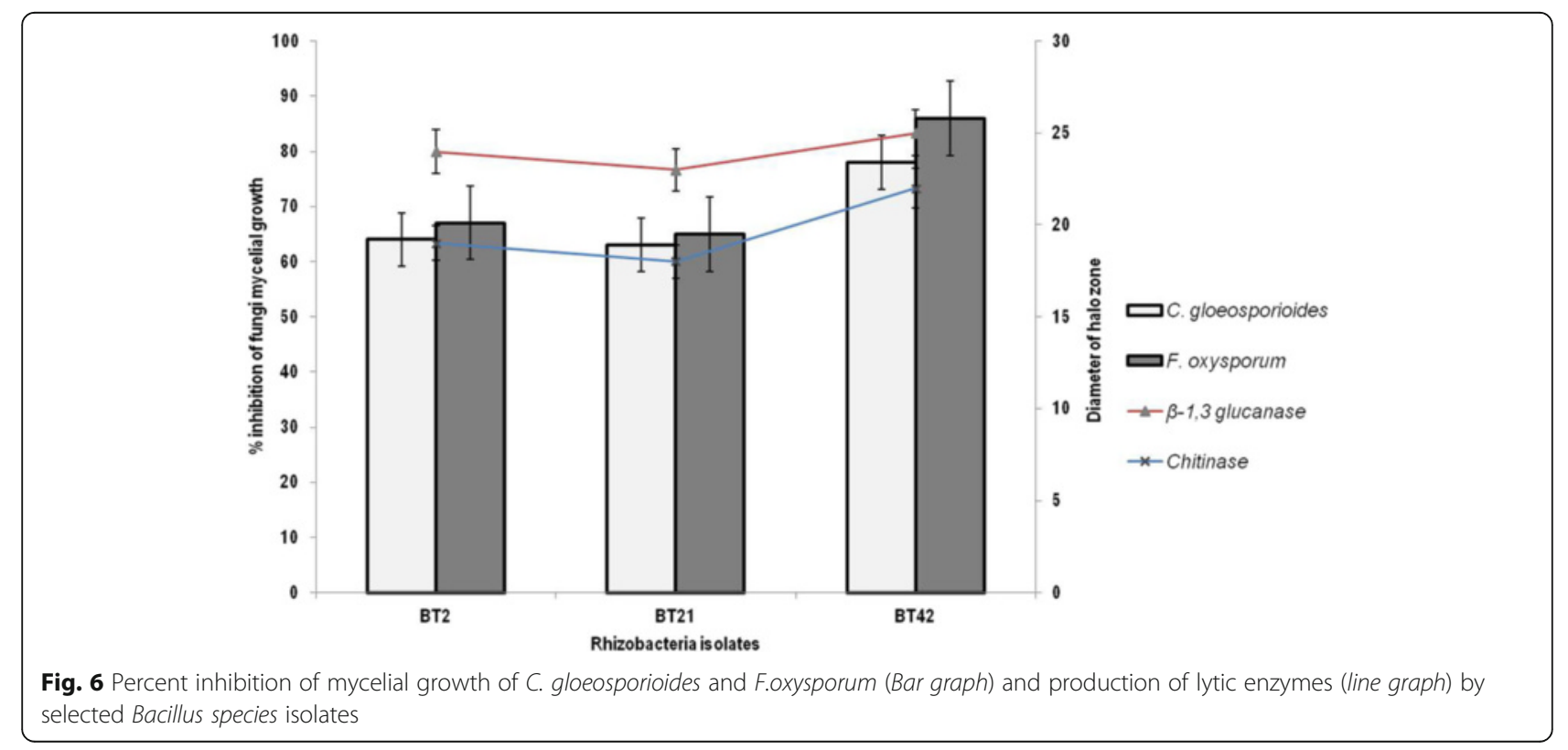




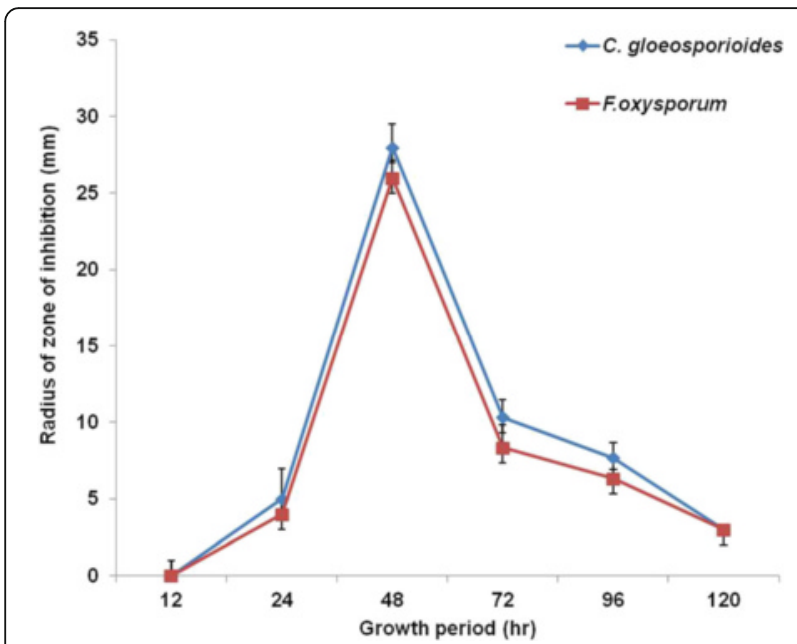

Fig. 7 The radius of inhibition of pathogenic fungi by metabolite extracted from BT42 at different period of growth. Error bar represents \pm SD

abundance of isotopes were considered. Based on the calculation we found that there were 13 carbons, 12 hydrogens, 2 nitrogens and 1 oxygens atom. From $\mathrm{m} / \mathrm{z}$ cloud the value of mass (i.e. 212.09) (Fig. 9b) is exactly matching with the compound harmine (CAS registry Number. 442-51-3) and its MS spectrum was matched to NIST database. Fourier transform infrared spectroscopy (FTIR) data of the compound $\mathrm{C} 1$ showed the presence of functional groups. The frequency at $3405 \mathrm{~cm}^{-1}$ indicates the presence of $-\mathrm{NH}$ Indole stretching, while aromatic $\mathrm{C}-\mathrm{H}$ stretching at $3044 \mathrm{~cm}^{-1}$, $-\mathrm{CH}$ of alkane stretching at $2958 \mathrm{~cm}^{-1}, \mathrm{C}=\mathrm{N}$ stretching at $1665 \mathrm{~cm}^{-1},-\mathrm{CH}$ of $-\mathrm{CH}_{3}$ bending at $1357 \mathrm{~cm}^{-1}$, asymmetrical $\mathrm{C}-\mathrm{O}-\mathrm{C}$ stretching at 1077 and $1231 \mathrm{~cm}^{-1}, \mathrm{C}-\mathrm{N}$ of Indole at $1100 \mathrm{~cm}^{-1}$, aromatic $\mathrm{C}=\mathrm{C}$ stretching at 1590 and $1448 \mathrm{~cm}^{-1},-\mathrm{CH}$ bending of aromatic ring at $864 \mathrm{~cm}^{-1}$ were observed (Fig. 10). Based on LC-MS data and FTIR assignment, the suggested formula for the compound is $\mathrm{C}_{13} \mathrm{H}_{12} \mathrm{~N}_{2} \mathrm{O}$ and its structural formula showed in Fig. 11.

Further confirmation of the compound was carried out by qualitative tests using the general reagent for alkaloids (Dragendroff's reagent) and it was found to be positive and specifically for the presence of indole derivates using glyoxylic-sulphuric acid test. Accordingly, the solution containing the $\mathrm{C} 1$ showed a positive test for the presence of alkaloid and showed a positive test for the presence of indole derivative, forming a purple to violet ring at the junction of two distinct phases when glyoxylic acid and the test solution mixed in the presence of conc. $\mathrm{H}_{2} \mathrm{SO}_{4}$. The secondary metabolite harmine could be the principal reason for inhibition of growth of $C$. gloeosporioides and F. oxysporum.

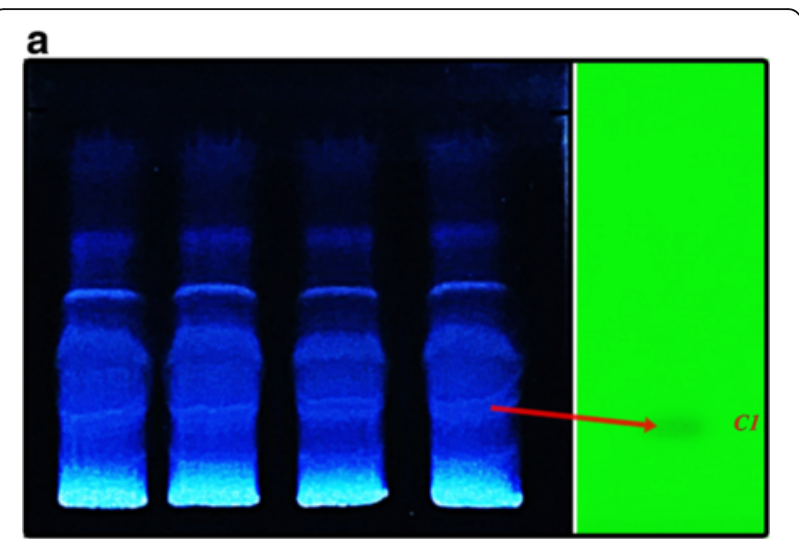

b
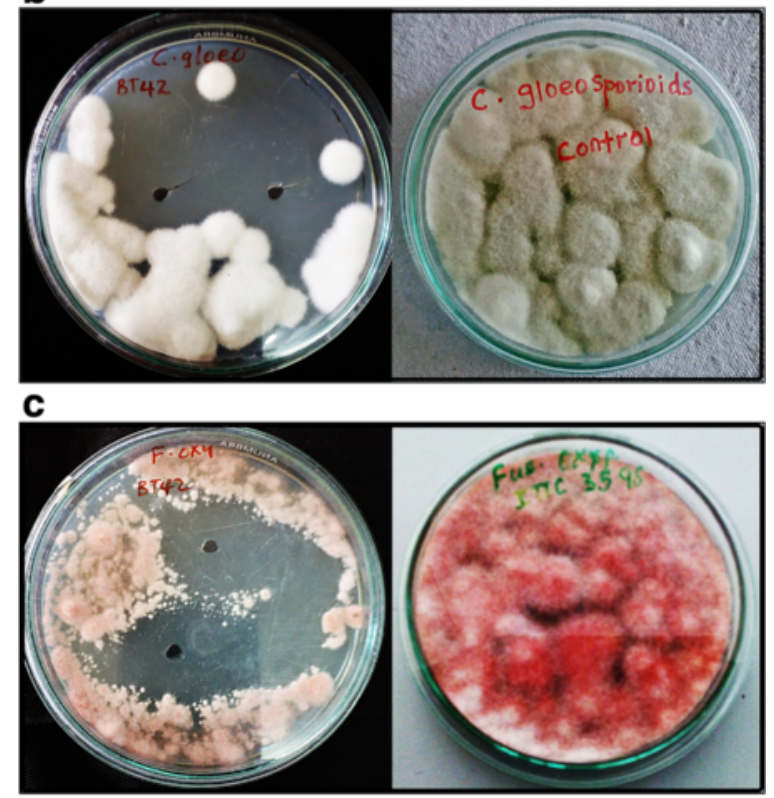

Fig. 8 TLC showing separation of extract and purified band of C1 (a), inhibition of growth of C. gloeosporioides by C1 (b) inhibition of growth of F. oxysporum by $\mathrm{C} 1$ (c)

\section{Discussion}

In the present study, we have isolated potent Bacillus species (BT42) that is able to inhibit C. gloeosporioides (78\%) and F. oxysporum (86\%). In a review of similar studies, Bacillus sp. strain RMB7, which has broad range antifungal activity showed $71 \%$ and $78 \%$ mycelial growth inhibition of $F$. oxysporum and $C$. gloeosporioides respectively [13]. BT42 produces known extracellular lytic enzymes (chitinase and $\beta$-1, 3-glucanase), which are significantly correlated with fungi mycelial growth inhibition. In a similar study conducted elsewhere, significant mycelial growth inhibition of G. xylarioides (anamorph: Fusarium xylarioides) by the chitinase producing Bacillus species isolate named as JU5444 was also reported [12]. Apart from chitinase and $\beta-1,3$-glucanase, BT42 produced protease and lipase that might be involved in the inhibition of the mycelial growth of C. gloeosporioides and 

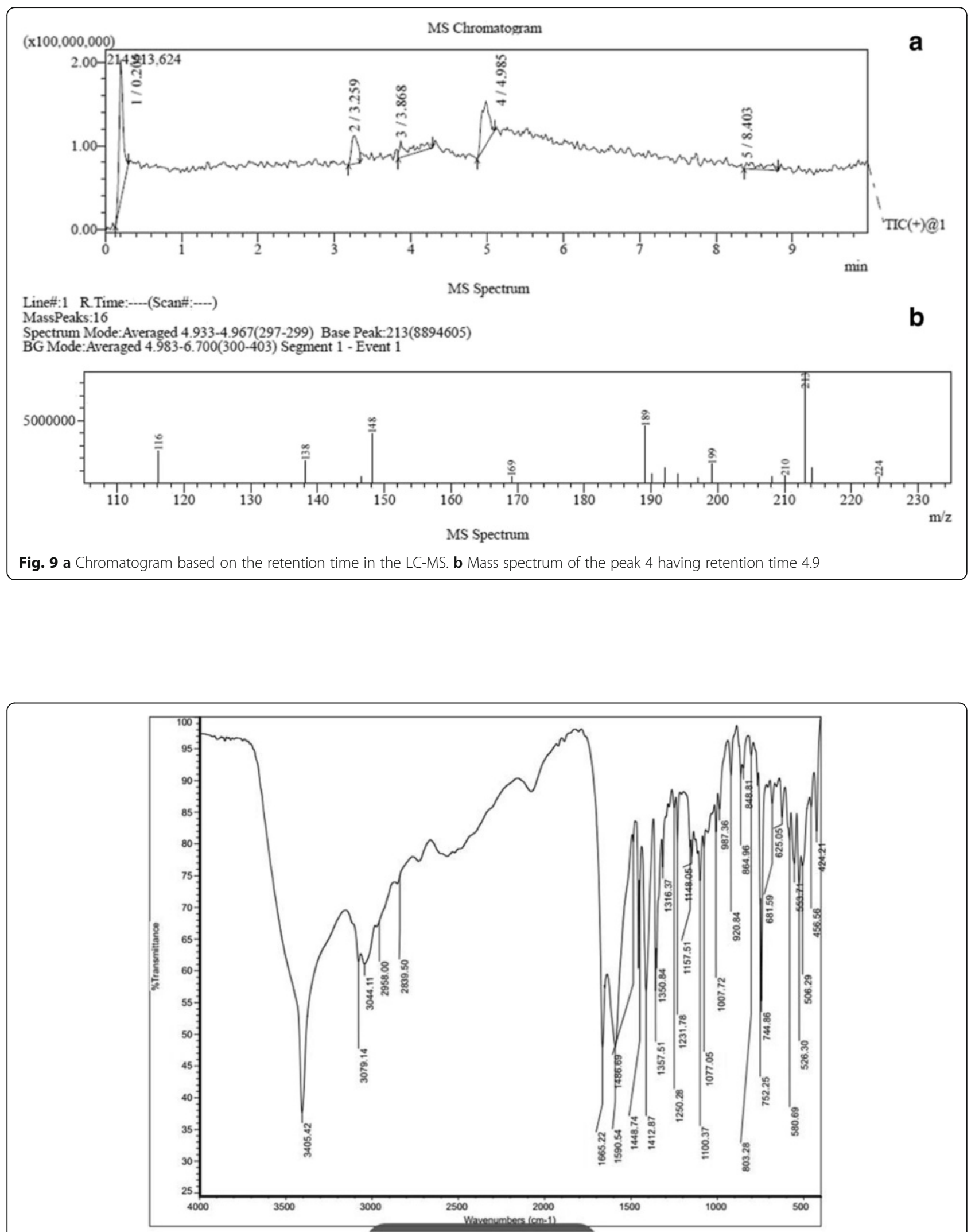

Fig. 10 FTIR data with the presence of functional groups in the potent compound C1, frequency values appeared in the figures represent the respective functional groups 


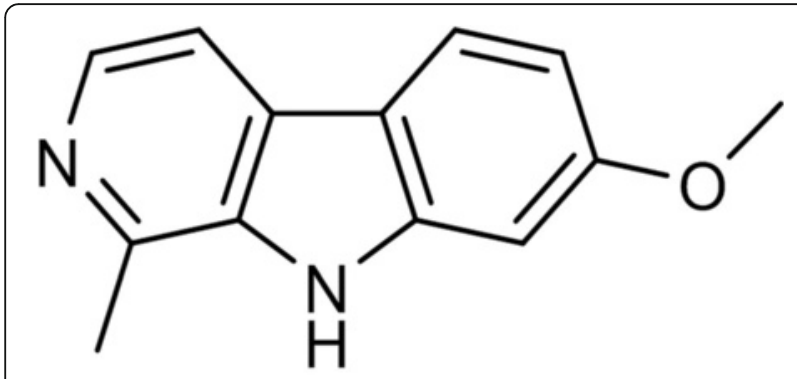

7-methoxy-1-methyl-9H-pyrido[3,4-b] indole

\section{Harmine}

Fig. 11 Structural formula and name of potent compound C1

F. oxysporum. Earlier reports indicated that protease [14, 15] and lipase production [12] by bacteria are associated with inhibition of mycelial growth of different fungi.

Since the statistical correlation of growth inhibition of pathogenic fungi and lytic enzyme produced were positive but mostly less than $0.9 \mathrm{r}$, more than one mechanism of inhibition of pathogenesis was suspected. The production of siderophore by BT42 might also be involved in the inhibition of fungi. Bacteria produce Siderophores during iron starvation. The previous report indicates that siderophores produced by Bacillus subtilis have got potential to inhibit the growth of $F$. oxysporum [16]. Bacillus amyloliquefaciens FZB42, which has maximum similarity with BT42, harbors genes responsible for the synthesis of siderophores [17].

Apart from production of lytic enzymes and siderophores, from the culture filtrate of BT42, we also isolated and identified antifungal compound, which is confirmed as Harmine [18]. Harmine is $\beta$-carboline alkaloid that was first isolated from Peganum harmala L $[19,20]$. Harmine is rarely reported from bacteria and it is mostly extracted from higher plants $[19,21]$. Harmine production in bacteria was limited to a few species including Enterococcus faecium, Myxobacter and Pseudomonas species [22-25]. However, the recent report by Saad and Zakaria demonstrated that Bacillus flexus isolated from fresh water produced harmine as a mechanism of inhibition of toxic cyanobacteria and this was considered as the first report from Bacillus species [26]. In our present study, we identified harmine from the cultural extract of Bacillus species (BT42) isolated from root rhizosphere of $C$. arabica L., which is the first report of its type. This is the first report of inhibition of pathogens of C. arabica L., C. gloeosporioides and F. oxysporum by plant growth promoting rhizobacterium by an alkaloid harmine. The inhibitory activity of $\beta$-carboline alkaloids against different fungi that include $C$. gloeosporioides and $F$. oxysporum was recently described although the $\beta$-carboline alkaloids were extracted from the plant [21].
To sum up, the highest inhibition of C. gloeosporioides and F. oxysporum mycelial growth by the Bacillus species (BT42) is due to the synergistic effect of multiple mechanisms, which could be explained as the production of lytic enzymes and harmine, which is produced as an extracellular secondary metabolite.

Apart from biocontrol activity, Bacillus species (BT42) also exhibited plant growth promoting characteristics (IAA production, ammonia production, phosphate solubilization and zinc solubilization) that directly involved in plant growth promotion and indirectly in the pathogen suppression. The production of IAA by rhizobacteria is so important in supporting plant growth and development by interfering with the endogenous IAA produced by the plant and serve in defense responses [27-29]. Studies showed that Bacillus amyloliquefaciens is known to produce a substantial amount of IAA [17, 30]. Another important trait displayed by Bacillus species (BT42) is the ability to produce an enzyme ACC deaminase. The production of ACC deaminase by the BT42 is also vital in plant-microbe interaction; that enables the host plant to withstand stress due to drought and flooding by decreasing the endogenous ethylene levels. Studies showed that Bacillus amyloliquefaciens has the versatile potential for both plant growth and biocontrol activity of different phytopathogenic fungi, which is similarly strengthened by our present study [17, 31-33].

The high disease incidence caused by C. gloeosporioides and $F$. oxysporum were significantly reduced in the presence of BT42 due to the potential biocontrol activity of this bacterium. In BT42 treated C. arabica L seeds, germination occurred much better than that of untreated, which indicates that the isolate facilitated germination of the C. arabica L. seeds by the extracellular production of PGPR traits that supported the germination.

\section{Conclusions}

In conclusion, we have isolated a Bacillus species (BT42), which shows the versatility of direct and indirect plant growth promoting traits. BT42 showed maximum similarity with Bacillus amyloliquefaciens in NCBI BLASTn result and shows maximum similarity with the same bacterium by $\mathrm{Ez}$ taxon database. This bacterium could effectively inhibit pathogens of $C$. arabica L. The mechanisms of inhibition of C. gloeosporioides and F. oxysporum were found to be the production of lytic enzymes, siderophores as well as antifungal compounds. The major antifungal compound was identified as harmine (a member of $\beta$-carboline alkaloids), which is not previously reported as a mechanism of action of PGPR. To this end, the BT42 isolate can be a potential candidate to be used as a biocontrol of $C$. gloeosporioides and $F$. oxysporum and also as biofertilizer. 


\section{Methods}

\section{Sampling site and sample collection}

Rhizosphere soil samples of Coffea arabica L. were collected from two different fields at Khusalnagar, Karnataka, South India. These sites are located between $12^{0} 28^{\prime} 05.7^{\prime \prime} \mathrm{N}$ and $75^{0} 57$ '51.7'E. Soil samples were collected after consent was obtained from coffee farm owners.

\section{Isolation and Identification of bacterial isolate}

Isolation of rhizobacteria from root rhizosphere of $C$. arabica L. was performed as previously stated [12]. The pure isolates were further confirmed by standard microbiological techniques [34]. Pure isolates were stored at $-20{ }^{\circ} \mathrm{C}$ with $50 \%$ glycerol for further study. Primers fD1 (forward, 5'-AGAGTTTGATCCTGGCTC AG-3') and rP2 (reverse, 5' ${ }^{\prime}$ ACGGCTACCTTGTTACG ACTT-3'), were obtained from Eurofins (India) and used for the amplification of $16 S$ rRNA gene [35]. A PCR mixture $(20 \mu \mathrm{l})$ consisting of: $2.5 \mu \mathrm{l}$ of $10 \mathrm{X} \mathrm{\textrm {Mg } ^ { 2 + }}$ buffer containing $15 \mathrm{mM} \mathrm{Mg}{ }^{2+}, 1 \mu \mathrm{l}$ of Taq polymerase enzyme $(1 \mathrm{U} / \mu \mathrm{l}), 3 \mu \mathrm{l}$ of $\mathrm{dNTP}$ mixture $(3 \mathrm{mM}), 1 \mu \mathrm{l}$ of each primer $(10 \mathrm{pM}), 2 \mu \mathrm{l}$ of template DNA $(50-100 \mathrm{ng} / \mu \mathrm{l})$ and $9.5 \mu \mathrm{l}$ of Milli-Q water was prepared. DNA thermocycler was used for the amplification of the DNA at $94{ }^{\circ} \mathrm{C}$ for $3 \mathrm{~min}$, followed by 32 cycles of $30 \mathrm{~s}$ at $94{ }^{\circ} \mathrm{C}, 15 \mathrm{~s}$ at $54{ }^{\circ} \mathrm{C}$ and $1 \mathrm{~min}$ at $72{ }^{\circ} \mathrm{C}$ with an extension of $72{ }^{\circ} \mathrm{C}$ for $5 \mathrm{~min}$. One $\mu \mathrm{l}$ of PCR product along with standard DNA ladder $(1.5 \mathrm{~kb})$ were loaded on a $0.8 \%$ agarose gel containing $3 \mu \mathrm{l}$ of ethidium bromide in 1X TAE buffer and electrophoresed at $100 \mathrm{~V}$ for $35 \mathrm{~min}$. The PCR product checked and visualized using a UV transilluminator. The PCR product purified and sequenced at Eurofins Genomics India Pvt Ltd, Bangalore, India.

Using the NCBI website, Basic Local Alignment Search Tool (BLASTn) used for checking the 16S rRNA gene sequences with comparative sequences of reference strains. Mega 6 software used for the construction of phylogenetic tree after the sequences aligned. To carry out phylogenetic analysis, sequences of $16 \mathrm{~S}$ rRNA of thirteen reference strains that are important for comparison downloaded from NCBI database http://www.ncbi.nlm.nih.gov.

\section{In vitro antagonistic study of bacteria against pathogens}

In vitro antagonistic study of the bacteria was carried out against two fungal pathogens Colletotrichum gloeosporioids sp.coffee (ITCC 7131) and Fusarium oxysporum (ITCC 3595). Both the cultures were obtained from Indian Type Culture Collection (ITCC), Division of Plant pathology, Indian agricultural research institute, New Delhi 110012 (India).

Potato dextrose agar used for dual culture during the antagonistic studies of bacteria against fungal pathogens. Percent fungal radial growth inhibition was calculated as stated below [12].
Fungal mycelial growth inhibition $=[(\mathrm{C}-\mathrm{T}) / \mathrm{C}] \times 100$

Where,

$$
\begin{aligned}
\mathrm{T}= & \text { fungal radial mycelial growth during dual culture } \\
& \text { (Bacteria }+ \text { fungus) } \\
\mathrm{C}= & \text { fungal radial mycelial growth } \\
& \text { (without antagonistic bacteria) } .
\end{aligned}
$$

\section{Experimental design and bioassay}

The experiment involved only one factor (the rhizobacteria antagonist). In the experiment Bacillus sp BT42, used as it showed the highest reduction of radial mycelial growth of both C. gloeosporioides and F. oxysporum. Healthy Coffea arabica L. seeds collected from selected healthy coffee plants. First, the exocarp of the coffee fruits was removed and kept in water at $30{ }^{\circ} \mathrm{C}$ for $24 \mathrm{~h}$ with the other fruit part (mesocarp and endocarp) then mesocarp was removed by washing them and left on a tray to dry [36]. Surface sterilization of coffee seeds was carried out as reported elsewhere [37]. Two hundred sixteen surface sterilized coffee seeds randomly distributed in four groups: untreated (36 seeds), rhizobacteria treated (36 seeds), rhizobacteria + fungi (72 seeds) and fungi (72 seeds) for the experiment. The bacterium grown in nutrient broth under shaking condition of $150 \mathrm{rpm}$ for $18-20 \mathrm{~h}$ ( 1 X $10^{8}$ cells $/ \mathrm{ml}$ ) at $30{ }^{\circ} \mathrm{C}$ were used for coating seeds. The surface sterilized seeds inoculated in the liquid culture of bacteria and dried in aseptic condition under laminar flow hood for $30 \mathrm{~min}$. In the same manner, spore suspensions of $C$. gloeosporioides ( 1 X $10^{4}$ spores $/ \mathrm{ml}$ ) inoculated and dried under laminar flow hood for $30 \mathrm{~min}$. Similarly, bacteria and fungi surface coated on the seed of C. arabica L., in the same manner, one after the other. Surface sterilized seeds without any treatment taken as controls.

Seeds in each group (bacterial treated, fungi infected, fungi + bacteria treated and untreated) placed on pre-sterilized Whatman filter paper in separate Petri plate (three replicates). Plates with the coffee seeds incubated at $30+1{ }^{\circ} \mathrm{C}$, dampness of the seeds maintained by spraying 1-1.5 ml distilled water on filter paper as necessary and any physiological changes in each group of seeds inspected and recorded daily. The experiment carried out in completely randomized design under controlled conditions. The experiment performed in three replicates.

\section{Studies of plant growth promoting traits} Qualitative and quantitative test for Siderophore production Rhizobacterium was grown in iron-free medium $\left(\mathrm{K}_{2} \mathrm{HPO}_{4}\right.$, $6.0 \mathrm{~g} \mathrm{~L}^{-1} ; \mathrm{KH}_{2} \mathrm{PO}_{4}, 3.0 \mathrm{~g} \mathrm{~L}^{-1} ; \mathrm{MgSO}_{4} 7 \mathrm{H}_{2} \mathrm{O}, 0.2 \mathrm{~g} \mathrm{~L}$ ${ }^{1} ;\left(\mathrm{NH}_{4}\right)_{2} \mathrm{SO}_{4}, 1.0 \mathrm{~g} \mathrm{~L}^{-1}$; and Succinic acid $\left.4.0 \mathrm{~g} \mathrm{~L}^{-1}, \mathrm{pH} 7.0\right)$ and incubated for $48 \mathrm{~h}$ at $30{ }^{\circ} \mathrm{C}$ with constant shaking of 
$150 \mathrm{rpm}$ [38]. After $48 \mathrm{~h}$ of incubation, the fermented broth centrifuged at 10,000 $\mathrm{rpm}$ for $15 \mathrm{~min}$ and supernatant were taken and checked for the presence of siderophore. For estimation of siderophore, $0.5 \mathrm{ml}$ of supernatant was mixed with CAS reagent and absorbance was calculated at $630 \mathrm{~nm}$ [38]. Percent siderophore units calculated using the formula:

$\%$ siderophore units $=(\mathrm{Ar}-\mathrm{As}) / \mathrm{Ar} \times 100$

Where, $\mathrm{Ar}=$ absorbance of reference at $630 \mathrm{~nm}$ (CAS reagent) and $A s=$ absorbance of the sample at $630 \mathrm{~nm}$.

\section{Test for phytohormones production}

For the production of IAA, purified bacterium isolate was grown in Luria-Bertani (LB) broth under shaking condition $(150 \mathrm{rpm})$ around the clock at $30{ }^{\circ} \mathrm{C}$. Overnight grown culture centrifuged at 10,000 rpm for $15 \mathrm{~min}$ and the supernatant collected. To the supernatant (app. $2 \mathrm{ml}$ ) two drops of O-phosphoric acid added; the manifestation of pink color indicates IAA production by the rhizobacteria isolates. Quantitative estimation of IAA was done colorimetrically [39].

For the production of Gibberellic acid, bacterium isolate was grown in $100 \mathrm{ml}$ nutrient broth at $30{ }^{\circ} \mathrm{C}$ for $48 \mathrm{~h}$. The growth of bacterium was monitored by measuring turbidity at $600 \mathrm{~nm}$. For extraction of Gibberellic acid, $50 \mathrm{ml}$ of the culture was taken and centrifuged at $7500 \mathrm{rpm}$ for $10 \mathrm{~min}$. The supernatant was collected and $\mathrm{pH}$ was adjusted to 2.5 using $37 \% \mathrm{HCl}$. Supernatant extracted using ethyl acetate in 1:1 volume ratio [40]. Gibberellic acid quantitatively estimated by using a UV spectrophotometer at $254 \mathrm{~nm}$ [41].

\section{Test for ammonia production}

Rhizobacterium isolate grown in peptone water for 4 days at $30{ }^{\circ} \mathrm{C}$ in $50 \mathrm{ml}$ test tubes. In each test tube containing bacterial isolates, $1 \mathrm{ml}$ of Nessler's reagent added. The appearance of a faint yellow color is evidence of weak reaction and deep yellow to brownish color was confirmation of strong reaction [42].

\section{Test for zinc and phosphate solubilization}

Phosphate solubilizing ability of bacterium isolate was determined by the inoculation of overnight grown bacterial isolates on pre-solidified specific medium for phosphate solubilization test [43]. The rhizobacterium incubated for $96 \mathrm{~h}$ at $30{ }^{\circ} \mathrm{C}$ and any clear zone around the rhizobacterium colonies indicated phosphate solubilization. Quantitative determination of phosphate solubilizing activity was performed calorimetrically [44]. Zinc solubilization was performed by plate assay using modified Pikovskaya agar [45]. The rhizobacteria isolates were inoculated into a medium consisting of: ammonium sulfate $\left(1 \mathrm{~g} \mathrm{~L} \mathrm{~L}^{-1}\right)$, dipotassium hydrogen phosphate $\left(0.2 \mathrm{~g} \mathrm{~L}^{-1}\right)$, glucose $\left(10.0 \mathrm{~g} \mathrm{~L}^{-1}\right)$, magnesium sulfate $\left(0.1 \mathrm{~g} \mathrm{~L}^{-1}\right)$, potassium chloride $\left(0.2 \mathrm{~g} \mathrm{~L}^{-1}\right)$, Yeast $\left(0.2 \mathrm{~g} \mathrm{~L}^{-1}\right)$, distilled water $(1000 \mathrm{ml})$, $\mathrm{pH} 7.0$ and $0.1 \%$ insoluble zinc compounds $\left(\mathrm{ZnO}, \mathrm{ZnCO}_{3}\right.$ and $\mathrm{ZnS}$ ). The rhizobacteria isolate grown in this medium for $48 \mathrm{~h}$ at $28{ }^{\circ} \mathrm{C}$. The clear zone around the colony indicated solubilization of insoluble zinc compounds.

\section{Qualitative test for 1-Aminocyclopropane-1-carboxylate (ACC) deaminase}

ACC deaminase production was checked using Dworkin and Foster (DF) minimal salts medium [46]. To the pre-solidified DF minimal salts medium $3 \mathrm{mM}$ ACC solution sprayed and allowed to dry in aseptic condition for $10 \mathrm{~min}$ then bacterial isolates inoculated. After $48 \mathrm{~h}$ of incubation at $30{ }^{\circ} \mathrm{C}$, any growth of bacteria on the media was considered as ACC deaminase production [47].

\section{Studies of mechanisms of inhibition of pathogenic fungi Lytic enzymes production}

Test for Production of $\boldsymbol{\beta}-\mathbf{1}, \mathbf{3}$ glucanases, and chitinase Test for the production of $\beta-1,3$ glucanases was performed using laminarin as the only carbon source for growth of bacteria. Accordingly, the isolates were inoculated on media containing $\mathrm{Na}_{2} \mathrm{HPO}_{4}\left(6 \mathrm{~g} \mathrm{~L}^{-1}\right), \mathrm{KH}_{2} \mathrm{PO}_{4}$ $\left(3 \mathrm{~g} \mathrm{~L}^{-1}\right), \mathrm{NH}_{4} \mathrm{Cl}\left(0.5 \mathrm{~g} \mathrm{~L}^{-1}\right)$, yeast extract $\left(0.05 \mathrm{~g} \mathrm{~L}^{-1}\right)$, Agar $\left(15 \mathrm{~g} \mathrm{~L}^{-1}\right)$ and $0.05 \%$ laminarin, (Sigma) and incubated at $30{ }^{\circ} \mathrm{C}$ for $48 \mathrm{~h}$. After $48 \mathrm{~h}$ of incubation, the clear zones obtained. To visualize clearly, plates were flooded with a mixture of $0.666 \% \mathrm{KI}$ and $0.333 \%$ Iodine and isolates showing yellow clear zone around the bacterial colony confirmed as the production of $\beta-1,3$ glucanases.

For the checking of chitinase production, colloidal chitin was prepared from chitin powder (Hi-Media) for the preparation of the solid media. The compositions of solid media were colloidal chitin $1 \%(\mathrm{w} / \mathrm{v}), \mathrm{Na}_{2} \mathrm{HPO}_{4}$ $\left(6 \mathrm{~g} \mathrm{~L}^{-1}\right), \mathrm{NaCl}\left(0.5 \mathrm{~g} \mathrm{~L}^{-1}\right), \mathrm{KH}_{2} \mathrm{PO}_{4}\left(3 \mathrm{~g} \mathrm{~L}^{-1}\right) ; \mathrm{NH}_{4} \mathrm{Cl}$ $\left(1 \mathrm{~g} \mathrm{~L}^{-1}\right)$, yeast extract $\left(0.05 \mathrm{~g} \mathrm{~L}^{-1}\right)$ and agar $\left(15 \mathrm{~g} \mathrm{~L}^{-1}\right)$. The bacteria isolates were checked for their production of chitinase by observation of clear zone around the colonies after five days incubation at $30 \pm 1{ }^{\circ} \mathrm{C}$ [48].

Test for Production of Protease and Lipase Test for protease production was done using the protease specific medium as earlier described [49]. Similarly, the rhizobacteria isolates were checked for lipase enzyme using lipase media [2]. This media contains calcium chloride $0.1 \mathrm{~g}$, Peptone $10 \mathrm{~g}$, sodium chloride $5 \mathrm{~g}$, Agar $15 \mathrm{~g}$, distilled water 1 Liter, $10 \mathrm{ml}$ sterile Tween 20 . The bacterial isolates streaked on this medium and incubated at $27{ }^{\circ} \mathrm{C}$ for $48 \mathrm{~h}$, the clear zone around the bacterial colonies show the activity of lipase enzyme. 
Production of antifungal compound from isolate BT42

The test for antifungal activity of the culture filtrate was done as described elsewhere with modifications [50, 51]. Briefly, to check the antifungal activity of culture filtrate from strain BT42, a single colony of the isolate inoculated into Luria-Bertani (LB) broth and incubated for $120 \mathrm{~h}$ under shaking condition of $150 \mathrm{rpm}$ at $30{ }^{\circ} \mathrm{C}$. During the incubation period, $5 \mathrm{ml}$ samples taken from flasks at different time intervals and centrifuged at $12,500 \mathrm{rpm}$ for $10 \mathrm{~min}$ at $4{ }^{\circ} \mathrm{C}$. The cell pellet removed and supernatant filtered through a membrane filter (25 $\mathrm{mm})$ to remove any suspended cell. The collected sample tested for the antifungal activity by agar well diffusion method using $20 \mu \mathrm{l}$ of the culture filtrate and sterile broth as a control on Potato dextrose agar spread with a spore suspension of pathogenic fungi (1 X $10^{4}$ spores $/ \mathrm{ml}$ ). The plates incubated at $28{ }^{\circ} \mathrm{C}$ for 3 days.

Extracellular metabolites extracted from the $48 \mathrm{~h}$ grown culture filtrate using ethyl acetate. Accordingly, an equal amount of ethyl acetate added to the culture filtrate and both phases collected and concentrated to dryness. Active compounds obtained from both the phases subjected to the antifungal activity bioassay after dissolving them in methanol

\section{Purification, identification and characterization of antifungal compound}

The crude extract dissolved in methanol was separated by TLC on silica gel plates $(20 \times 20 \mathrm{~cm}, 0.5 \mathrm{~mm}$ thick, $\mathrm{G})$, developed in Isopropanol: ammonia: water (10:1.5:1, $\mathrm{v} / \mathrm{v})$ as the mobile phase. The TLC plate was visualized under UV transilluminator. Each specific band corresponding to specific metabolite eluted by carefully scraping from the TLC plate, suspended in methanol and checked for antifungal activity. The antifungal compound was once again subjected to TLC using the same as well as different solvent systems (chloroform: methanol 90:10; benzene: acetic acid 95:05; ammonia: methanol: chloroform $0.5: 1: 8.5)$ as stated above to check its purity. The purified compound characterized and identified using FTIR and LC-MS analysis. The alkaloid nature of the purified antifungal compound was also confirmed by a qualitative test using Dragendorff's reagent and glyoxylic-sulphuric acid test specific for indole derivatives as described elsewhere $[52,53]$.

\section{Statistical analysis}

IBM SPSS Statistics software version 19 was used to analyze the data related to correlations of fungal radial mycelial growth inhibition and lytic enzyme production. Similarly, one-way ANOVAs was used to compare the mean difference between treatments, and the level of significance was set at $P<0.05$.

\section{Abbreviations}

ACC: 1-Aminocyclopropane-1-carboxylate; BLAST: Basic Local Alignment Search Tool; C. arabica: Coffea arabica; C. gloeosporioides: Colletotrichum gloeosporioides; CAS: Chrome Azul S; DF: Dworkin and Foster; F. oxysporum: Fusarium oxysporum; FTIR: Fourier transform infrared spectroscopy; IAA: Indole-3-acetic acid; ITCC: Indian Type Culture Collection; LC-MS: Liquid chromatography-mass spectrometry; MS: Mass spectrometry; PDA: Photodiode anode; PGPR: Plant growth promoting rhizobacteria; TLC: Thin layer chromatography

\section{Acknowledgement}

We would like to thank BRD School of Biosciences, Sardar Patel University for lab facilities and the Indian Council for Cultural Relations (ICCR), as a sponsor of the scholarship for the first author. Mr. Parth Thakor is thankful to DST Inspire program for the fellowship. Authors are also thankful to Mr. Sampark Thakkar and Prof. Arabinda Ray from PDPIAS, Charusat for the critical evaluation of the LC-MS and FTIR portion of the manuscript. We thank DST, New Delhi for the assistance in general and for the PURSE central facility LC-MS sponsored under PURSE program grant vide sanction letter Do.No.SR/59/Z-23/2010/43 dated 16th March 2011.

\section{Funding}

No specific fund was obtained for this study; however, the study was supported by BRD School of Biosciences, Sardar Patel University, Vallabh Vidyanagar, Gujarat, India.

\section{Availability of data and materials}

The dataset generated for phylogenetic tree construction is available in the

Tree BASE repository, http://purl.org/phylo/treebase/phylows/study/TB2:S20152.

\section{Authors' contributions}

TK involved in designing of the study, experimentations, data analysis and interpretation, and write-up of the manuscript. VRT designed the study, supervised and guided the experimental process, and prepared the manuscript for publication. PT involved in LC-MS and FTIR data analysis and interpretation and manuscript writing. All the authors read and approved the final manuscript.

\section{Competing interests}

The authors declare that they have no competing interests.

Consent for publication

Not applicable.

Ethics approval and consent to participate

Not applicable.

\section{Author details}

${ }^{1}$ Department of Biology, Faculty of Natural and Computational Sciences, Mettu University, Mettu, Ethiopia. ${ }^{2}$ Present Address: BRD school of Biosciences, Sardar Patel University, Vallabh Vidyanagar 388120, India. ${ }^{3}$ BRD School of Biosciences, Sardar Patel University, Vadtal Road, Satellite Campus, Post Box No.39, Vallabh Vidyanagar 388120, Gujarat, India.

Received: 28 January 2016 Accepted: 15 November 2016 Published online: 18 November 2016

\section{References}

1. Amamo AA. Coffee production and marketing in Ethiopia. Eur J Bus Manag. 2014;6(37):109-22.

2. Muleta D. Microbial Inputs in Coffee (Coffea arabica L.) Production Systems, Southwestern Ethiopia. Implications for Promotion of Biofertilizer and Biocontrol Agents. Doctoral thesis,Swedish University of Agricultural Sciences/Uppsala.; 2007

3. Admasu W, Sahile S, Kibret M. Assessment of potential antagonists for anthracnose (Colletotrichum gloeosporioides) disease of mango (Mangifera indica L.) in North Western Ethiopia (Pawe). Arch Phytopathol Plant Prot. 2014:47(18):2176-86. doi:10.1080/03235408.2013.870110.

4. Hindorf $\mathrm{H}, \mathrm{Omondi} \mathrm{CO}$. A review of three major fungal diseases of Coffea arabica $L$. in the rainforests of Ethiopia and progress in breeding for resistance in Kenya. J Adv Res. 2011;2(2):109-20. doi:10.1016/j.jare.2010.08.006. 
5. Kilambo DL, Mabagala RB, Varzea VMP, Haddad F, Loureiro A, Teri JM. Characterization of Colletotrichum kahawae strains in Tanzania. Int J Microbiol Res. 2013;5(2):382-9.

6. Muleta D, Assefa F, Börjesson E, Granhall U. Phosphate-solubilising rhizobacteria associated with Coffea arabica L. in natural coffee forests of southwestern Ethiopia. J Saudi Soc Agric Sci. 2013. doi:10.1016/j.jssas.2012.07.002.

7. Nguyen THP, Säll T, Bryngelsson T, Liljeroth E. Variation among Colletotrichum gloeosporioides isolates from infected coffee berries at different locations in Vietnam. Plant Pathol. 2009;58(5):898-909. doi:10.1111/j.1365-3059.2009.02085.x.

8. Derso E, Waller JM. Variation among Colletotrichum isolates from diseased coffee berries in Ethiopia. Crop Prot. 2003;22:561-5. doi:10.1016/S0261-2194(02)00191-6.

9. Rutherford MA, Phiri N. Pests and Diseases of Coffee in Eastern Africa: A Technical and Advisory Manual. Wallingford, UK: CAB International; 2006

10. Sharma M, Kulshrestha S. Colletotrichum gloeosporioides: an anthracnose causing pathogen of fruits and vegetables. Biosci, Biotech Res Asia. 2015;12:1233-46.

11. Martínez EP, Hío JC, Osorio LA, Torres MF, Erika P. Identification of Colletotrichum species causing anthracnose on Tahiti lime, tree tomato, and mango. Agron Colomb. 2009;27(2):211-8.

12. Tiru M, Muleta D, Berecha G, Adugna G. Antagonistic Effects of Rhizobacteria Against Coffee Wilt Disease Caused by Gibberella xylarioides. Asian J Plant Pathol. 2013;7(3):109-22. doi:10.3923/ajppaj.2013.109.122.

13. Ali S, Hameed S, Imran A, labal M, Lazarovits G. Genetic, physiological and biochemical characterization of Bacillus sp.strain RMB7 exhibiting plant growth promoting and broad spectrum antifungal activities. Microb Cell Fact. 2014;13:144.

14. Chaiharn M, Chunhaleuchanon S, Kozo A, Lumyong S. Screening of rhizobacteria for their plant growth promoting activities. KMITL Sci Technol J. 2008:8(1):18-23.

15. Liao CY, Chen MY, Chen YK, et al. Characterization of three Colletotrichum acutatum isolates from Capsicum sp. Eur J Plant Pathol. 2012;133(3):599-608. doi:10.1007/s10658-011-9935-7

16. Patil S, Bheemaraddi CM, Shivannavar TC, Gaddad MS. Biocontrol activity of siderophore producing Bacillus subtilis CTS-G24 against wilt and dry root rot causing fungi in chickpea. IOSR J Agric Vet Sci. 2014;7(9):63-8.

17. Chen $\mathrm{XH}$, Koumoutsi $\mathrm{A}$, Scholz R, et al. Comparative analysis of the complete genome sequence of the plant growth-promoting bacterium Bacillus amyloliquefaciens FZB42. Nat Biotechnol. 2007;25(9):1007-14. doi:10.1038/nbt1325.

18. Silverstein RM, Webster FX, Kiemle DJ. Spectrometric Identification of Organic Compounds. New York: John Wiley \& Sons; 2005. p. 1-550.

19. Berrougui $H$, Isabelle $M$, Cloutier M, Hmamouchi M, Khalil A. Protective effects of Peganum harmala L. extract, harmine and harmaline against human low-density lipoprotein oxidation. J Pharm Pharmacol. 2006;58(7):967-74. doi:10.1211/jpp.58.7.0012.

20. de Meester C. Genotoxic potential of beta-carbolines: a review. Mutat Res. 1995;339(3):139-53.

21. Li Z, Chen S, Zhu S, Luo J, Zhang Y, Weng Q. Synthesis and fungicidal activity of $\beta$-Carboline alkaloids and their derivatives. Molecules. 2015;20(8): 13941-57. doi:10.3390/molecules200813941.

22. Aassila H, Bourguet-Kondracki ML, Rifai S, Fassouane A, Guyot M. Identification of harman as the antibiotic compound produced by a tunicate-associated bacterium. Mar Biotechnol (NY). 2003;5(2):163-6. doi:10.1007/s10126-002-0060-7.

23. Bohlendorf B, Forche E, Bedorf N, et al. Antibiotics from Gliding Bacteria, LXXIII Indole and Quinoline Derivatives as Metabolites of Tryptophan in Myxobacteria. European J Org Chem. 1996. doi:10.1002/jlac.199619960108.

24. Kodani S, Imoto A, Mitsutani A, Murakami M. Isolation and identification of the antialgal compound, harmane (1-methyl- $\beta$-carboline), produced by the algicidal bacterium, Pseudomonas sp.K44-1. J Appl Phycol. 2002;14(2):109-14.

25. Zheng L, Chen H, Han X, Lin W, Yan X. Antimicrobial screening and active compound isolation from marine bacterium NJ6-3-1 associated with the sponge Hymeniacidon perleve. World J Microbiol Biotechnol. 2005;21(2): 201-6. doi:10.1007/s11274-004-3318-6

26. Alamri SA, Mohamed ZA. Selective inhibition of toxic cyanobacteria by Bcarboline-containing bacterium Bacillus flexus isolated from Saudi freshwaters. Saudi J Biol Sci. 2013;20(4):357-63. doi:10.1016/j.sjbs.2013.04.002.

27. Mohite B. Isolation and characterization of indole acetic acid (IAA) producing bacteria from rhizospheric soil and its effect on plant growth. J Sci Plant Nutr. 2013. doi:10.4067/S0718-95162013005000051.
28. Weselowski B, Nathoo N, Eastman AW, Macdonald J, Yuan Z-C. Isolation, identification and characterization of Paenibacillus polymyxa CR1 with potentials for biopesticide, biofertilization, biomass degradation and biofuel production. BMC Microbiol. 2016. doi:10.1186/s12866-016-0860-y.

29. Shao J, Li S, Zhang N, et al. Analysis and cloning of the synthetic pathway of the phytohormone indole-3-acetic acid in the plantbeneficial Bacillus amyloliquefaciens SQR9. Microb Cell Fact. 2015;14(1): 130. doi:10.1186/s12934-015-0323-4.

30. Ait A, Noreddine $K$, Chaouche K, Ongena M, Thonart P. Biocontrol and plant growth promotion characterization of Bacillus Species isolated from Calendula officinalis Rhizosphere. Indian J Microbiol. 2013;53(4):447-52. doi:10.1007/s12088-013-0395-y.

31. Yu GY, Sinclair JB, Hartman GL, Bertagnolli BL. Production of iturin A by Bacillus amyloliquefaciens suppressing Rhizoctonia solani. Soil Biol Biochem. 2002;34(7):955-63. doi:10.1016/S0038-0717(02)00027-5.

32. Jiang C-H, Wu F, Yu Z-Y, et al. Study on screening and antagonistic mechanisms of Bacillus amyloliquefaciens 54 against bacterial fruit blotch (BFB) caused by Acidovorax avenae subsp. citrulli. Microbiol Res. 2015;170: 95-104. doi:10.1016/j.micres.2014.08.009.

33. Shahzad R, Waqas M, Khan AL, et al. Seed-borne endophytic Bacillus amyloliquefaciens RWL-1 produces gibberellins and regulates endogenous phytohormones of Oryza sativa. Plant Physiol Biochem. 2016; 106(September):236-43. doi:10.1016/j.plaphy.2016.05.006.

34. Ahmad F, Ahmad I, Khan MS. Screening of free-living rhizospheric bacteria for their multiple plant growth promoting activities. Microbiol Res. 2008; 163(2):173-81. http://dx.doi.org/10.1016/j.micres.2006.04.001.

35. Weisburg WG, Barns SM, Pellettier DA, Lane DJ. 16S ribosomal DNA amplification for phylogenetic study. J Bacteriol. 1991;173(2):697-703.

36. Rosa SDVF da, Mcdonald MB, Veiga AD, Vilela FdeL, Ferreira IA. Staging coffee seedling growth: a rationale for shortenning the coffee seed germination test. Seed Sci Technol. 2010;38:421-431.

37. Shanmugam V, Kanoujia N. Biological management of vascular wilt of tomato caused by Fusarium oxysporum f.sp. lycospersici by plant growthpromoting rhizobacteria mixture. Biol Control. 2011;57(2):85-93. doi:10.1016/j.biocontrol.2011.02.001.

38. Sayyed RZ, Badgujar MD, Sonawane HM, Mhaske MM, Chincholkar SB Production of microbial iron chelators (siderophores) by fluorescent Pseudomonads. Indian J Biotechnol. 2005;4(4):484-90.

39. Tsavkelova EA, Cherdyntseva TA, Klimova SY, Shestakov Al, Botina SG, Netrusov Al. Orchid-associated bacteria produce indole-3-acetic acid, promote seed germination, and increase their microbial yield in response to exogenous auxin. Arch Microbiol. 2007;188(6):655-64. doi:10.1007/s00203-007-0286-x.

40. Cho KY, Sakurai A, Kamiya Y, Takahashi N, Tamura S. Effects of the new plant growth retardants of quaternary ammonium iodides on gibberellin biosynthesis in Gibberella fujikuroi. Plant Cell Physiol. 1979;20(1):75-80.

41. Kumar PKR, Lonsane BK. Immobilized growing cells of Gibberella fujikuroi P3 for production of gibberellic acid and pigment in batch and semicontinuous cultures. Appl Microbiol Biotechnol. 1986;28:537-42.

42. Cappuccino JC, Sherman N. Microbiology; a laboratory manual. New York: Benjamin/Cumming Pub. Co; 1992. p. 125-79.

43. Pikovskaya RI. Mobilization of phosphorus in soil in connection with the vital activity of some microbial species. Mikrobiologiya. 1948;17:362-70.

44. King EJ. The colorimetric determination of phosphorus. Biochem J. 1932;26:292

45. Saravanan VS, Subramoniam SR, Raj SA. Assessing in vitro solubilization potential of different zinc solubilizing bacterial (ZSB) isolates. Brazilian J Microbiol. 2004;35(1-2):121-5. doi:10.1590/\$1517-83822004000100020.

46. Ramamoorthy $V$, Viswanathan $R$, Raguchander T, Prakasam V, Samiyappan R. Induction of systemic resistance by plant growth promoting rhizobacteria in crop plants against pests and diseases. Crop Prot. 2001;20:1-11.

47. Penrose DM, Glick B. Methods for isolating and characterizing ACC deaminase containing plant growth promoting rhizobacteria. Physiol Plant. 2002;1 18:10-5.

48. Renwick A, Campbell R, Coe S. Assessment of in vivo screening systems for potential biocontrol agents of Gaeumannomyces graminis. Plant Pathol. 1991:40:524-32.

49. Smibert RM, Krieg NR. Phenotypic characterization. In: Gerhardt P, Murray RGE, Wood WA, Krieg NR, editors. Methods for General and Molecular Bacteriology. Washington DC: American Society of Microbiology; 1994. p. 607-54.

50. Kumar A, Saini S, Wray V, Nimtz M, Prakash A, Johri BN. Characterization of an antifungal compound produced by Bacillus sp. strain $A(5) F$ that inhibits Sclerotinia sclerotiorum. J Basic Microbiol. 2012:52(6):670-8. doi:10.1002/jobm.201100463. 
51. Vilarinho BR, Silva JP, Pomella AWV, Marcellino LH. Antimicrobial and plant growth-promoting properties of the cacao endophyte Bacillus subtilis ALB629. J Appl Microbiol. 2014;116:1584-92. doi:10.1111/jam.12485.

52. Paech K, Tracey MV. Modern Methods of Plant Analysis/Moderne Methoden der Pflanzenanalyse. 1st edition, Biemann K, Boardman NK, Breyer B, et al., editors. Berlin, Heidelberg: Springer; 1962.p.1-509. doi:10.1007/978-3-642-45993-1.

53. Crotti AEM, Paul J, Gates JLCL, NPL. Based characterization of $\beta$-carbolinesmutagenic constituents of thermally processed meat. Mol Nutr Food Res. 2010;54:433-9. doi:10.1002/mnfr.200900064.

Submit your next manuscript to BioMed Central and we will help you at every step:

- We accept pre-submission inquiries

- Our selector tool helps you to find the most relevant journal

- We provide round the clock customer support

- Convenient online submission

- Thorough peer review

- Inclusion in PubMed and all major indexing services

- Maximum visibility for your research

Submit your manuscript at www.biomedcentral.com/submit
Biomed Central 